TRADITIONAL MEDICINE AND PHARMACOLOGY. ACHIEVEMENTS, INNOVATIONS, AND ALTERNATIVES

\title{
2.4 Connective tissue metabolism indexes of patients with reactive arthritis and pyelonephritis
}

A significant increase of reactive arthritis disease $(\operatorname{ReA})$ is observed all over the world in recent years, what in the overall structure of rheumatic arthritis disease currently consists $5-11 \%$ [143]. ReA incidence is growing simultaneously, that is 30 200 citizens per 100000 of the adult population $[144,145]$. Nowadays, one of the most burning problems is ReA diagnosis and its treatment [146].

Most of the laboratory findings that are used at ReA diagnosis have not specific character, and reflecting of inflammation process presence and activity [147, 148, 149]. Methods that characterise such connective tissue specific components exchange as collagen and proteoglycan, show more informational content about the progress of pathosis of the affected joints and the extent of reducing the intensity of process under the influence of treatment. Metabolic abnormalities in such system as "proteoglycans and collagen" and change of enzymatic reactions often are preceded by many complications, including chronic kidney disease and renal failure.

113 patients have been examined and divided into two groups: in the 1-st group there were patients with Reactive Arthritis (ReA), on its I-III degree of activity and JFI (Joint Functional Insufficiency) on I-III degree $(n=65)$; the 2-nd group consists of patients with ReA and Chronic Kidney Disease (CKD): Chronic Pyelonephritis (CP) in the exacerbation phase, chronic renal failure (CRF) 0-I stage $(n=48)$. The diagnosis is determined in accordance with the criteria of ESSG (European Spondyloarthropathy Study Group) using international criteria (4th International Workshop on Reactive Arthritis, Berlin, 1999).

The diagnosis of $\mathrm{CP}$ was based on: clinical symptoms (pain, dysuric, intoxication, and arterial hypertension), laboratory tests (urine test, Nechyporenko and Zimnitskiy urine tests), radiographic (descending urography), and ultrasound diagnosis (ultrasonography of kidneys). Groups of patients were grouped on age, sex, duration and activity of comorbid diseases. The control group was formed of 20 healthy persons (HP). 
TRADITIONAL MEDICINE AND PHARMACOLOGY. ACHIEVEMENTS, INNOVATIONS, AND ALTERNATIVES

Metabolism changes of carbohydrate and protein components of the extracellular matrix were determined by the level of free hydroxyproline in (FOP) and hydroxyproline bound with protein (BOP), hexuronic acid (HUA), hexosamine (HA), seromucoid (SM), sialic acid (SA). State of blood plasma proteolytic activity was studied by determining the intensity of lysis azoalbumin (degradation of low molecular weight proteins), azocasein (proteolysis of high molecular weight proteins), azokol (collagenolysis) and the level of plasma collagenolytic activity (PCA).

Scientific researches were performed in accordance with ethical guidelines for biomedical researches with Human subject research what is set at The Declaration of Helsinki developed for the medical community by the World Medical Association. Patients gave written informed consent on the research participation. Mathematical processing was performed with the help of the computer program SPSS 20,0 (Statistical Package for the Social Sciences).

The average disease duration was $24,4 \pm 4,7$ months. Patients average age was 32,5 $\pm 1,2$ years. First group of examined patients consisted of persons $(n=50,76,92 \%$ ), who have been diagnosed of ReA for the first time, and who had chronic course of disease $(\mathrm{n}=15 ; 23,08 \%)$. In the group of patients with comorbid course of ReA and CP was observed chronic disease in $79,17 \%(n=38)$, and recurrent course in $20,83 \%(n=10)$. Leading to the clinical picture of patients in both groups was asymmetrical articular syndrome with joint disease of the upper and lower extremities that was leading in clinical picture of both groups of patients. In most cases, mono- and oligoarthritis were observed. Polyarthritis was approved in patients with chronic ReA against a background of CKD.

During disease exacerbation in patients with ReA level of FOP in blood, what is a marker of collagen catabolism, significantly was higher than in a control group in 1.3 times $(p<0.05)$, while in the second group it was higher in 1.5 times $(p<0.05)$. Simultaneously, the significant increase of BOP in blood was observed in both 1-st and 2-nd in 2.3 and 2.5 times in comparison with HP group ( $<<0.05$ ), what is the indicator of increased collagen synthesis (Table 1). Parallel growth of BOP and FOP 
TRADITIONAL MEDICINE AND PHARMACOLOGY. ACHIEVEMENTS, INNOVATIONS, AND ALTERNATIVES

simultaneously can be an indicator of collagen synthesis increase and collagen degradation, and the formation of weaken collagen.

Table 1.

Connective tissues indexes in patients with reactive arthritis

\begin{tabular}{|c|c|c|c|}
\hline Indexes & $\begin{array}{c}\text { HP } \\
(n=20)\end{array}$ & $\begin{array}{l}\text { 1-st group } \\
(\mathrm{n}=65)\end{array}$ & $\begin{array}{l}\text { 2-nd group } \\
\qquad(\mathrm{n}=48)\end{array}$ \\
\hline FOP, mcmole/1 & $11,61 \pm 0,58$ & $15,16 \pm 0,20 *$ & $17,2 \pm 1,2 * / * *$ \\
\hline BOP, mcmole/1 & $28,22 \pm 0,4$ & $63,72 \pm 2,36 *$ & $65,7 \pm 3,0 *$ \\
\hline HUA, mcmole/1 & $1,19 \pm 0,07$ & $0,65 \pm 0,33$ & $0,60 \pm 0,21 *$ \\
\hline HA, mcmole/l & $5,21 \pm 0,31$ & $10,12 \pm 0,24 *$ & $10,56 \pm 0,42 *$ \\
\hline $\mathrm{SA}, \mathrm{mcmole} / 1$ & $2,36 \pm 0,05$ & $4,11 \pm 0,31 *$ & $5,4 \pm 0,2 * / * *$ \\
\hline SM & $0,18 \pm 0,09$ & $0,76 \pm 0,44$ & $0,74 \pm 0,01 *$ \\
\hline $\mathrm{PCA}, \mu \mathrm{m} / \mathrm{h} / 1$ & $5,29 \pm 0,06$ & $7,67 \pm 0,26$ * & $8,02 \pm 0,33 *$ \\
\hline $\begin{array}{l}\text { PA (azoalbumin), } \\
\mathrm{mcg} / \mathrm{mL} \text { per } 1 \text { hour }\end{array}$ & $2,99 \pm 0,28$ & $4,78 \pm 0,54 *$ & $5,23 \pm 0,34 *$ \\
\hline $\begin{array}{l}\text { PA (azokazein) } \\
\mathrm{mcg} / \mathrm{mL} \text { per } 1\end{array}$ & $2,26 \pm 0,21$ & $4,01 \pm 0,23 *$ & $4,14 \pm 0,25 *$ \\
\hline $\begin{array}{l}\text { PA (azokol), } \\
\text { meg/mL per } 1\end{array}$ & $0,44 \pm 0,07$ & $0,8 \pm 0,05 *$ & $1,10 \pm 0,05 * / * *$ \\
\hline
\end{tabular}

The degree of BOP increase in blood becomes higher with increasing activity in both groups (Table 2), as well as the proliferation of "joint insult area" and the evidence of bone changes was determined after ultrasound and pneumoarthrography were made. 
TRADITIONAL MEDICINE AND PHARMACOLOGY. ACHIEVEMENTS, INNOVATIONS, AND ALTERNATIVES

Table 2.

Connective tissue index of contents in blood plasma of patients with reactive arthritis depending on the degree of activity $(\mathrm{M} \pm \mathrm{m})$

\begin{tabular}{|l|l|l|l|l|}
\hline \multirow{2}{*}{ Indexes } & \multicolumn{2}{|c|}{$\begin{array}{c}\text { 1-st group } \\
(\mathrm{n}=65)\end{array}$} & \multicolumn{2}{c|}{$\begin{array}{c}\text { 2-nd group } \\
(\mathrm{n}=48)\end{array}$} \\
\cline { 2 - 5 } & $\begin{array}{c}\text { I degree } \\
\text { of activity } \\
(\mathrm{n}=45)\end{array}$ & $\begin{array}{c}\text { II-III degree } \\
\text { of activity } \\
(\mathrm{n}=20)\end{array}$ & $\begin{array}{c}\text { I degree } \\
\text { of activity } \\
(\mathrm{n}=18)\end{array}$ & $\begin{array}{c}\text { II-III degree } \\
\text { of activity } \\
(\mathrm{n}=30)\end{array}$ \\
\hline FOP, mmol/L & $15,06 \pm 0,14$ & $15,36 \pm 0,23$ & $16,49 \pm 0,60 *$ & $\begin{array}{l}18,03 \pm 1,02 \\
* / * *\end{array}$ \\
\hline BOP, mmol/L & $62,45 \pm 1,21$ & $66,60 \pm 1,43$ & $65,26 \pm 1,41$ & $68,13 \pm 1,50 *$ \\
\hline HUA, mmol/L & $0,73 \pm 0,25$ & $0,47 \pm 0,13$ & $0,74 \pm 0,18$ & $0,52 \pm 0,21$ \\
\hline HA, mmol/L & $10,01 \pm 0,24$ & $10,35 \pm 0,11$ & $10,41 \pm 0,20$ & $10,65 \pm 0,39$ \\
\hline PCA, $\mu \mathrm{m} / \mathrm{h} / 1$ & $7,55 \pm 0,26$ & $7,92 \pm 0,16$ & $7,79 \pm 0,33$ & $8,20 \pm 0,23$ \\
\hline $\begin{array}{l}\text { PA (azoalbumin) } \\
\text { mcg/mL per 1 hour }\end{array}$ & $4,46 \pm 0,25$ & $5,49 \pm 0,24$ & $5,05 \pm 0,33$ & $5,39 \pm 0,32$ \\
\hline $\begin{array}{l}\text { PA (azokazein) } \\
\text { mcg/mL per 1 hour }\end{array}$ & $3,89 \pm 0,25$ & $4,26 \pm 0,23$ & $3,98 \pm 0,31$ & $4,25 \pm 0,25$ \\
\hline $\begin{array}{l}\text { PA (azokol), } \\
\text { mcg/mL per 1 hour }\end{array}$ & $0,78 \pm 0,07$ & $0,85 \pm 0,05$ & $1,05 \pm 0,05$ & $\begin{array}{l}1,12 \pm 0,07 \\
* / * *\end{array}$ \\
\hline $\begin{array}{l}\text { Note: * the difference is accurate in comparison with the 1-st group of patients } \\
\text { with RA indexes on I degree of activity (p<0,05); } \\
* * \text { - the difference is accurate in comparison with the 1-st group of patients with } \\
\text { RA indexes on II-III degrees of activity (p<0,05). }\end{array}$ \\
\hline
\end{tabular}

During the study of both 1st and 2nd groups there was observed a statistically significant increase of HA content almost in 2.0 times compared to the control group $(\mathrm{p}<0.05)$. A significant HUA decrease was determined in 2-nd group of patients compared to the control group $(\mathrm{p}<0.05)$, but in the 1-st group HA content had a tendency to decrease. This can be indicator of glycoprotein synthesis increase on the background of proteoglycan synthesis decreased. As far as hexosamine is a part both of proteoglycans and glycoproteins, so its increase in the blood can be indicator of decay enhancement of connective tissue carbohydrate-protein components. Increase of $\mathrm{HA}$ is a factor that activates inflammation and abnormal bacterioagglutinin formation. 
TRADITIONAL MEDICINE AND PHARMACOLOGY. ACHIEVEMENTS, INNOVATIONS, AND ALTERNATIVES

Longstanding inflammation of connective tissue causes its degradation. Increase of HA advances changes of other indexes which characterize the functional status of the connective tissue.

Direct correlation of HA amount in blood depends from degree of inflammatory activity (Table 2). Increase of the average level of HA in blood is determined when conventional laboratory methods are not more informative. A progressive increase of HA content in both groups was already determined at II-III degree of activity. There is a significant pathogenetic relation between metabolic proteoglycans and immunological disorders processes in this group of patients. Metabolic products of connective tissues ground substance have antigenic specificities and are able to stimulate immune reactions in tissues. In most cases asymmetric mono -or oligoarthritis of upper and lower joints with a domination of II-III degree of activity was determined in most cases $(85,0 \%)$ at patients who have ReA with comorbid chronic pyelonephritis.

In the 2-nd group it was determined the impact of comorbid chronic pyelonephritis over the ReA activity increase, in comparison to RA isolated course in terms of inflammation and connective tissue reaction: leukocytosis, increased erythrocyte sedimentation rate $(\mathrm{ESR})(\mathrm{p}<0,05)$, levels of C-reactive protein in blood in 2,5 times, $(\mathrm{p}<0,05)$, sialic acids in 1,3 times $(\mathrm{p}<0,05)$, seromucoid in 1,6 times ( $\mathrm{p}$ $<0,05)$, fibrinogen on 11,2\% $(\mathrm{p}<0,05)$, globulin on $25,5 \%(\mathrm{p}<0,05)$, decrease of albumin in blood at 19,6\% $(\mathrm{p}<0,05)$, BOP in 1,2 times, and PA in 1.4 times $(\mathrm{p}<0.05)$ (Table 3). All these obtained results point to the $\mathrm{CP}$ active formation phase within $\operatorname{ReA}$ activity. 
TRADITIONAL MEDICINE AND PHARMACOLOGY. ACHIEVEMENTS, INNOVATIONS, AND ALTERNATIVES

Table 3 .

Clinical and biochemical blood analysis indexes in patients with reactive arthritis depending on the degree of activity $(\mathrm{M} \pm \mathrm{m})$

\begin{tabular}{|c|c|c|c|c|}
\hline \multirow[t]{2}{*}{ Indexes } & \multicolumn{2}{|c|}{$\begin{array}{l}\text { 1-st group } \\
\qquad(\mathrm{n}=65)\end{array}$} & \multicolumn{2}{|c|}{$\begin{array}{l}\text { 2-nd group } \\
\qquad(\mathrm{n}=48)\end{array}$} \\
\hline & $\begin{array}{l}\text { I degree of activity } \\
\qquad(\mathrm{n}=45)\end{array}$ & $\begin{array}{l}\text { II-III degree of } \\
\text { activity } \\
(\mathrm{n}=20)\end{array}$ & $\begin{array}{l}\text { I degree of } \\
\text { activity } \\
(\mathrm{n}=18)\end{array}$ & $\begin{array}{l}\text { II-III degree of } \\
\text { activity } \\
(\mathrm{n}=30)\end{array}$ \\
\hline Hemoglobin (g/l) & $142,4 \pm 2,2$ & $130,4 \pm 2,1 *$ & $115,8 \pm 2,0 *$ & $105,4 \pm 1,8 * / * *$ \\
\hline Erythrocyte $\left(\times 10^{12} / 1\right)$ & $4,6 \pm 0,2$ & $3,8 \pm 0,1 *$ & $4,0 \pm 0,2^{*}$ & $3,2 \pm 0,1 * / * *$ \\
\hline Leucocyte $\left(\times 10^{9} / 1\right)$ & $10,3 \pm 0,5$ & $13,2 \pm 0,6^{*}$ & $13,0 \pm 0,3^{*}$ & $15,6 \pm 0,2 * / * *$ \\
\hline $\operatorname{ESR}(\mathrm{mm} / \mathrm{h})$ & $12,9 \pm 0,5$ & $18,7 \pm 0,7^{*}$ & $16,5 \pm 0,9 *$ & $39,8 \pm 0,8 * / * *$ \\
\hline CRP (mg/l) & $4,6 \pm 2,5$ & $25,6 \pm 3,1^{*}$ & $18,1 \pm 3,7^{*}$ & $64,6 \pm 2,7 * *$ \\
\hline Sialic acids (mmol/1) & $3,6 \pm 0,1$ & $4,3 \pm 0,2^{*}$ & $4,2 \pm 0,1^{*}$ & $5,4 \pm 0,2 * / * *$ \\
\hline Fibrinogenous (g/l) & $4,1 \pm 0,1$ & $5,0 \pm 0,2^{*}$ & $4,6 \pm 0,1^{*}$ & $5,9 \pm 0,2 * / * *$ \\
\hline Whole protein $(\mathrm{g} / \mathrm{l})$ & $73,7 \pm 1,1$ & $78,7 \pm 1,0^{*}$ & $70,3 \pm 1,2$ & $63,7 \pm 1,0 * / * *$ \\
\hline Albumins (\%) & $56,2 \pm 0,6$ & $48,4 \pm 1,1^{*}$ & $45,0 \pm 1,1^{*}$ & $39,5 \pm 1,0 * / * *$ \\
\hline Globulins (\%) & $43,8 \pm 0,6$ & $51,6 \pm 0,6^{*}$ & $55,0 \pm 0,8^{*}$ & $60,5 \pm 0,6 * / * *$ \\
\hline $\mathrm{A} / \mathrm{G}$ & $1,28 \pm 0,03$ & $0,94 \pm 0,04 *$ & $0,82 \pm 0,02 *$ & $0,65 \pm 0,02 * / * *$ \\
\hline \multicolumn{5}{|c|}{$\begin{array}{l}\text { Note: * - the difference is accurate in comparison with the } 1 \text {-st group of patients with RA indexes } \\
\text { on I degree of activity }(p<0,05) \text {; } \\
\text { ** - the difference is accurate in comparison with the } 1 \text {-st group of patients with RA indexes on II- } \\
\text { III degrees of activity }(p<0,05) \text {. }\end{array}$} \\
\hline
\end{tabular}

Patients of 1-st and 2-nd groups showed a significant increase of PCA indicators in 1.4 times and 1.5 times in comparison to as HP group $(p<0,05)$. Lysis of low molecular weight protein growth in patients with ReA was observed in comparison to the control group: at the 1 -st group in 1.6 times, at the 2 -nd in 1.7 times $(p<0,05)$. Such intense proteolytic degradation of macromolecular proteins underwent changes, and this degradation was higher than the control in 1.8 times in both groups $(p<0,05)$. A significant increase of azokol lysis at the 1-st and the 2-nd group was determined during the study of plasma collagenolytic activity in comparison to the control group in 1.8 
times and 2.5 times $(p<0,05)$, where in the indicator exceeded in 1.4 times in the second group compared to the individuals of the first tested group ( $\mathrm{p}<0,05)$.

Thus, examination of the connective tissue state in patients with comorbid course of reactive arthritis and chronic kidney disease showed a significant increase of free and bound with protein hydroxyproline levels in blood, collagenolytic and proteolytic activity in plasma, what is indication of simultaneous increase of synthesis and collagen degradation on the background of collagenolysis activation. Determined significant increase of hexosamine and hexuronic acid content decrease indicates point to the increase glycoproteins synthesis against a background of decreased proteoglycans synthesis. Greatest importance in the diagnostic algorithm of progression and ReA clinical course have such indicators as levels of free and bound with protein hydroxyproline in blood, hexosamine and degree collagenolytic activity of blood plasma (intensivity of azokol lysis), what showed a direct relation to the degree of inflammation activity. Increase of ReA activity degree was found in the group of patients with comorbid course of reactive arthritis and chronic pyelonephritis in comparison to isolated ReA case in terms of inflammation and connective tissue reaction. Future research prospects: to study and propose a new method in the diagnosis of reactive arthritis and development on its background of chronic pyelonephritis based on the cluster and classification analysis methods and construct practical recommendations that can be used in clinical practice. 